\title{
In her bones: second wave "women's time" in Tanith Lee's The Winter Players
}

\author{
Eileen Donaldson \\ Department of English Studies \\ University of South Africa \\ donale@unisa.ac.za
}

\begin{abstract}
During feminism's second wave (circa 1960-1980) a particular approach to time gained ground and was explored by many cultural feminist activists, thinkers and writers. This feminine time was conceived of as cyclical and organic rather than masculine, mechanistic and linear and developed out of the essentialist celebration of "Woman" that dominated cultural feminism during this period. These cultural feminists called for an embracing of "women's time" which, they argued, would liberate women whose identities had been limited by the expectations of a patriarchal Western world and the patrilinear temporality it prescribed. Although their terms are considered problematically essentialist today, this remains an interesting moment in both feminist history and debates regarding temporality. This paper discusses fantasy author and feminist, Tanith Lee's evocation and exploration of second wave cultural feminism's "women's time" in her 1976 novella The Winter Players. In this novella Lee's protagonist is doomed to repeat a static, limited role for all time and in order to break free, steps into an alternative cyclical women's time that undoes the authority

of the paternalistic his-story that traps her. Once in this temporal space, she draws on both her own magical power and that of a female continuum of priestesses to reweave patrilinear time, in so doing empowering the women of her world to claim their right to public space/ time.
\end{abstract}

Keywords: gender studies; cyclical time; Tanith Lee; second wave feminism; linear time; women's time

Beginning in the 1960s and continuing into the early 80s, during what is now considered feminism's second wave, time came under scrutiny and like many other supposedly "natural" and "neutral" phenomena, was identified by feminists as one of the mechanisms used by a "hegemonic patriarchy" to keep "universal woman" in her place (Mitchell, 1984; Johles-Forman and Sowton, 1989; Braidotti, 1994). Karen Davies argues that prior to this feminist interrogation, "time is taken for granted, it is assumed that we all know what time is and that we share a common definition. Time is genderless" (Davies, 1990:15); second wave feminists demonstrated that time was both gendered and imbued with a patriarchal ideology that disempowered women (Collard, 1988; Ffeuffer-Kahn, 1989; Jardine, 1985; Donovan, 2001; Murphy, 2001). The reappraisal of time and claiming the 'right to time' became an important aspect of the second wave feminist project. In 1973 Mary Daly foregrounded the crucial nature of this project, writing that, "for women entrance into our own space and time is another way of expressing integrity and transformation. [...] When women move out of patriarchal space and time, there is a surge of new life" (1973:43). In the interest of claiming this surge of new life for women, second wave feminisms offered various methods of counteracting patrilinear time's dominance of women.

In this article, I briefly outline the approaches that governed this second wave interrogation of patriarchal time, using the term 'patrilinear' to designate the linear temporality associated with patriarchal culture. I then demonstrate that this interrogation of time carried over into some secondwave feminist fiction of the time through a literary analysis of Tanith Lee's 1973 novella The Winter Players. 
It is not surprising that while second-wave feminism was gaining ground as a movement, feminist speculative fiction was emerging as a distinct sub-genre of SF (speculative fiction includes fantasy and science fiction that speculates about alternative socio-cultural patterns). The women's liberation movement affected what women could say, how they were seen and the images used to represent them in fiction. So although there had been women writing what could be qualified as feminist SF before the 1960s and 70s (Mains, 2009:41; Leif-Davin, 2009:45-46), it is really during this period that SF was uncompromisingly co-opted by feminist authors and scholars (Baccolini, 2000; Pearson, 2006; Higgins, 2009). In this new fictional space feminist authors could articulate the political positions of various feminisms in a creative way and speculate about the ramifications of having feminist demands met (or not met). As feminist SF theorists Helen Merrick, Donna Haraway and Katie King argue, in this way feminist speculative fiction became as much a 'body of knowledge' functioning as an 'apparatus for the production of feminist culture' as was feminist theory or activism (Merrick, 2009:2; Haraway, 1991: 162-3; King, 1994:xv-xvi). Although Tanith Lee may not define herself as a feminist author, the 'woman question' pervades her writing (Clute and Nicholls, 1999: 424) which often explores a female protagonist's attempt to 'shape her world' (ibid, 700); because of this her body of work most certainly influences the 'production of feminist culture' and may be studied as such. In this article, I draw critical attention to Lee's second wave fantasy novella The Winter Players because of its interrogation of women's position in time. In this text, Oaive (Lee's protagonist) is trapped in a His-story that limits women's roles and agency. However, when she steps out of patrilinear time into an 'other', feminine, time she accesses a powerful magic embedded in her bones. Liberated and empowered, she then returns to patrilinear time and transforms the pattern of her patriarchal society. Like other second-wave feminist SF texts in which the authors defy the authority of patrilinear time - works such as Woman on the Edge of Time (1976) by Marge Piercy, Joanna Russ's The Adventures of Alyx (1967-1970) and Octavia Butler's Kindred (1979) - Lee's The Winter Players offers insights into the 'surge of new life' available to women who construct a new relationship to time.

Briefly, second wave feminists trace the division of time into gendered modes to the patriarchal West's age-old division of all phenomena into binary opposites:

\begin{abstract}
With the work of Parmenides (c515-399 BCE) Western philosophy, and the culture which it both reflects and informs, began to articulate a metaphysic, a logic, and an epistemology which would systematically disadvantage women for the next twenty-five hundred years. Parmenides posited a dualistic metaphysics and a complementary epistemology organised around two and only two logically coherent possibilities, the way of 'is' and the way of 'is not'. This is the first recorded theorisation of what philosopher Karen Warren (1988) shows is the 'logic of domination' that structures western culture to this day. (Orr, 2006:1)
\end{abstract}

For feminists, this dualistic metaphysic entrenched the division of reality into sets of gendered opposites designated broadly by the "masculine" (the way of "is") and the "feminine" (the way of "is not"), with the masculine privileged over the feminine (de Beauvoir, 1953; Cixous, 1975 reprinted in Marks and de Courtivron, 1981:96). Second Wave feminists argue that this binary also influences western conceptualisations of lived time so that two gendered temporal modes dominate: the linear and the cyclical (Davies, 1990:19). Linear time is considered masculine because it is the measurable time of events, scientific progress and economic production, in short, the public time of patriarchal civilisation. Cyclical time, the private time of reproduction, domesticity, creativity and mysticism is gendered feminine. Historically, women have been relegated to the private realm governed by cyclical time and dismissed from the public arena of male-dominated industry and history (Davies, 1990; Chanter, 2001; Burchill, 2006; Orr, 2006), so that the gendering of time affects not only how they formulate their time consciousness but how their lives are shaped by that consciousness (Davies, 1990:9). Having identified the role linear temporality plays in maintaining the limitation of women's actions, the problem for second wave feminisms became one of offering solutions to and methods by which to counteract the authority of patrilinearity and empower women. 
In probably the most renowned article on time from the second wave, "Women's Time" published in 1979, Julia Kristeva delineates the approaches she believes chronological generations of feminists have taken with regard to ameliorating women's position in patriarchal society through a recasting of women's relationship to time. Her argument is that "time is concretely tied to sexual difference" so that being dismissed from linear time casts women (and the feminine) in the position of the "other", maintaining them in a position that is powerless and disenfranchised (Keltner, 2011:83, 96-97). Although her analysis focuses on European feminisms (Keltner, 2011:96), the overarching approaches Kristeva observes seems to describe the approaches of American feminisms too. The first generation, the suffragists, "aspired to gain a place in linear time as the time of project and history" (in Moi, 1986: 193). The overarching intentions of the suffragists to gain equal rights in terms of education, the right to work and the right to vote reveal a desire to be admitted to the linear time of public, political endeavour. Keltner writes that this "movement not only eradicated the differences between women. It's universalist and progressive aspirations sought to eradicate the alienation of women by emphasising women's and men's sameness" (2011: 98).

Kristeva's second generation, chronologically equivalent to the rise of second wave feminism, responded to the universalism of the first generation by focusing on the specificity of "women's experience". In this phase the dominant attitude is that "linear temporality has been almost totally refused" (in Moi, 1986:194) because the feminist desire to assert a "women's identity" that was not prescribed by patriarchy not only demanded the

[r] ecognition of an irreducible identity, without equal in the opposite sex and, as such, exploded, plural, fluid, in a certain way non-identical, [but that] this feminism [thus] situates itself outside linear time [and] rejoins, on the one hand, the archaic (mythical) memory and, on the other, the cyclical or monumental temporality of marginal movements. (ibid, 194-195)

To some degree having gained the political and public aims of first wave feminism, but being disillusioned by the limitations of that success, second wave feminism thus turns inward to explore a sense of "women's self" unmediated by patrilinear "truths". Kristeva suggests that this turning inward aligns this feminist project with a private, cyclical temporality at odds with patrilinear time.

And finally, Kristeva posits that a third generation should follow the second wave and encourage the co-existence of the solutions offered by the two previous generations, calling for both "insertion into history and the radical refusal of the subjective limitations imposed by this [patrilinear] history's time" on the "irreducible difference" feminists want to assert. As Keltner suggests, "For this generation, according to Kristeva, sexual difference must be analysed according to differing relationships to power, language and meaning":

Kristeva thus proposes an understanding of sexual difference that reflects varying relations to the social-symbolic contract or, in other words, an understanding of the individual sexed subject as a boundary being at the threshold of two (spatio)temporalities: (1) the linear time of the social-symbolic contract and (2) the cyclical, monumental times of maternal existence. (Keltner, 2011:99)

Because of this, the perspective of the third generation is more nuanced than that of the previous two. For this generation, an empowered woman has access to both temporal modalities and is thus able to recast her relationship to the power dynamic maintained in patrilinear time.

Of course, "Women's Time" offers a more complex consideration of time than I have described above, introducing what will become Kristeva's decades-long theorising of the relationship between temporality, difference and the feminine (Beardsworth, 2004: 257; Keltner, 2011:15). It may therefore appear disingenuous of me to use her description of 'generations' so literally in this article. I do so, however, because I find it curious that, on the surface of it, the generational perspectives Kristeva delineates appear to co-exist so clearly during the second wave. My contention is that the perspectives she observes through feminist history describe the disparate approaches of second wave liberal, socialist and cultural feminists, and that the perspective of her third generation begins to appear in some fiction of the time, as I show in my reading of Tanith Lee's The Winter Players.

To cite this article: Eileen Donaldson (2017) In Her Bones: Second Wave "Women's Time" in Tanith Lee's The Winter Players, Scrutiny2, 22:2, 112-127, DOI: 10.1080/18125441.2017.1311361 
Although Kristeva attributes the desire for access to linear time to the suffragists who demanded equal civic rights, this agenda speaks to both the liberal and socialist feminisms of the second wave: for both linear time was complicit with the patriarchal ideologies of humanism and capitalism that denied women equality with men. Imelda Whelehan suggests that the core of liberalism (the faith in man's capacity to reason) both elevates man above the level of animals and asserts his superiority over them (1995:27). In this ideology man is also "humanity's standard issue and woman (merely) a grace note to complement and please him" as Jean Jacques Rousseau argued even as he expressed the "doubt (that) natural rights and liberty even pertained to such docile, childish people" as women (Stansell, 2010:19). This early liberal attitude influenced the denial of any but the most rudimentary education for women, their lack of legal powers and their submissive position in the family. It also enforced the segregation of public and private realms: the public being that of men, rational endeavour, economics and so on; and the private - the domestic, whimsical and irrational realm to which women were naturally suited. Early liberal feminism's desire for access to linear time and equality with men thus derived from the need to ameliorate the practical situations of women. This need continued into the second wave during which liberal feminist groups such as NOW fought for equal pay for equal work, legislation dealing with rape and domestic abuse, access to equal education and the right to contraception and abortion. Liberal feminism argued that "natural" domestic duties should not keep women from the linear time of public human endeavour.

And, as Whelehan observes "the origins of liberal philosophy are co-existent with the rise of capitalism" (1995:27) because both liberalism and capitalism affirm the public realm of commerce from which women are dismissed. In response to this, second wave socialist feminisms challenged the assumption that women's duties in the private sphere (specifically reproduction) rendered them incapable of performing in the public sphere of production. Because socialist feminism superseded Marxist feminism "largely [as a] result of Marxist feminists' dissatisfaction with the essentially gender-blind character of Marxist thought" (Tong, 1989:173), it challenged both oppressive class structures and oppressive patriarchal ideology in which the private was the sphere of unpaid, "voluntary" domestic labour performed by women. For them domestic labour kept women from the public agora and enforced an existence of banal passivity; they specifically challenged the capitalist ideology that women were objects synonymous with reproductive passivity rather than productive activity (Beer, 1989:74). The demand for access to patrilinear productive time is thus also central to the second wave socialist feminist agenda and positions them in Kristeva's first generation.

In contrast to these liberal and socialist agendas, second wave radical feminism called for a rejection of patriarchal culture and the creation of a separatist "women's culture". However, the various voices that contributed to this strand of feminism differ greatly in the degree to which they call for a "woman's culture", what they see as constituting this woman's culture and the effect they hoped such a culture would have. Second wave cultural feminism in particular can be equated with Kristeva's second generation because its gynocentric project calls for a rejection of linear time and the reclamation of feminine time as the "natural" temporality of the feminine, here conflated with (universal) women. This approach celebrated the differences between women and men and generated a body of theory variously called "cultural feminism, the 'woman-centered school' and 'gynocentrism/gynandry"' (Evans, 1995:18). Their focus on the personal, lived experiences of women (Stansell, 2010:244) seemed to reveal a temporality rooted in the primal (and supposedly undeniable) experience of the female body. It was women's monthly menses, their ability to give birth, the quasimystical experience of motherhood that opened women up to the experience of a time that was qualitatively "other" from the patrilinear norm. In "Women's Time" Kristeva describes it thus:

As for time, female subjectivity would seem to provide a specific measure that essentially retains repetition and eternity from among the multiple modalities of time known throughout the history of civilisations. On the one hand there are cycles, gestation and the eternal recurrence of a biological rhythm whose regularity and unison (...) is experienced as extrasubjective time, cosmic time and the occasional vertiginous visions [of] unnameable jouissance. On the other hand, and perhaps as a consequence, there is the massive presence of 
a monumental temporality, without cleavage or escape, which has so little to do with linear time (which passes) that the very word 'temporality' hardly fits. (Kristeva, 1986:191)

In 1971 psychoanalyst and theologian Ann Belford Ulanov suggested something very similar. She writes that

[f]or the feminine style of consciousness, time is qualitative rather than quantitative. We feel time as periodic and rhythmic, as waxing and waning, as favourable and unfavourable. The moon symbolises this qualitative time in its measuring of months by its own fullness and leanness. The moon cycle also represents the mysterious - and unconscious - and, in Jungian terms, feminine, rhythms of fertility, of growth, of birth, of withdrawal, of decline and death. In this sense, time is cyclical (and) each woman experiences this in the blood tides of her menstrual cycle and its attendant psychological effects. (1971:175)

It makes sense in the context of cultural feminism's focus on the differences between men and women that these theorists would ground their language in images of the female body. Women's lived experiences suggested that patrilinear time did not encompass all human experience, and the language of the female body provided linguistic markers through which to explore these elided experiences.

Looking back on it this theorising is fairly romantic and, arguably, counterproductive. It would certainly seem so to later feminisms which criticised the homogenisation (and idealisation) of "women's experiences" by writers who were predominantly white, middle-class and university educated. But for cultural feminists the value of the gynocentric project lay in the fact that it created a space from which the Other could mobilise an initial offensive against that which had marginalised and silenced it in the first place.

From a cultural feminist perspective, then, women's time was cyclical, gestative and separate from masculine linear time. Because of this, and because their language relied so heavily on the female body, cultural feminists involved in articulating the processes and properties of feminine time found themselves returning to pre-industrial mythical and archetypal images of the Great Cosmic Mother (Daly, 1973:xiii; Caputi, 1992:425; Larrington, 1992:427). Given that she was cyclical time incarnate the symbols and images associated with her could be used by feminist theorists and authors alike as a kind of short-hand to signify the disruption of patrilinear time by the feminine Other (Caputi, 1992:433). Images that suggest the womb (spaces that generate life) and the grave (from which the dead are reborn) foregrounded the essential feature of feminine time: because the Goddess is always both "[t]he fertile womb out of which all life comes and the darkness of the grave to which it returns" (Edinger, 1968), cyclical time is primarily regenerative, unlike linear time which "progresses" steadily towards a final death (Gottner-Abendroth, 1984:113). Feminine space/time encourages becoming and thus resists the fatalism of patrilinear time.

For Kristeva's third generation, the approaches of the first and second generations would coexist. This third generation would thus value both linear and cyclical time equally and claim access to both temporal modalities. Because of this, what is generated in cyclical time may be birthed into linear time, allowing becoming and difference to affect the public agora and initiate social progress: linear time becomes more fertile for the eruption of the feminine, and cyclical time has public consequence. My contention is that this third generation also appears during the second wave and is reflected in some feminist speculative fiction of the time. As Annis Pratt observes, second wave women's fiction "manifests alienation from normal concepts of time and space precisely because the presentation of time by persons on the margins of day-to-day life inevitably deviates from ordinary chronology" (1981:11). Their alienation from the patrilinear norm enabled feminist authors to experiment with the ideas of Kristeva's second and third generations in their texts. Tanith Lee's exploration of time in The Winter Players seems to demonstrate the position of this third generation.

Briefly, Lee's tale follows a priestess who is called to time travel in order to stop an evil sorcerer from freezing time into the repetition of a single linear pattern. Oaive steps out of linear time into an alternative chronological space described in the gynocentric terms of cultural feminism. There she To cite this article: Eileen Donaldson (2017) In Her Bones: Second Wave "Women's Time" in Tanith Lee's The Winter Players, Scrutiny2, 22:2, 112-127, DOI: 10.1080/18125441.2017.1311361 
discovers the full extent of her power which originates in her bones and is perpetuated by a continuum of priestesses through the ages. This in itself is a significant, gynocentric image: for women time is an embodied, lived experience. Oaive's power comes from the temporal knowing 'in her bones', a 'biological clock' as it were, whose otherness interrupts linear time and enables change to occur. Empowered, Oaive returns to patrilinear time, defeats the sorcerer and transforms her society, claiming access to the previously male-dominated agora for herself and all women. Lee's exploration of time in this novel therefore seems to acknowledge the importance of both gynocentric cyclical time as explored by cultural feminists and the liberal and socialist need for change in patrilinear time itself - the perspective Kristeva predicts of her third generation. When Oaive repositions herself in time, she recasts her relationship to power and meaning.

In this novella Oaive's agency is overtly influenced by the temporality that dominates each stage of the story. At the beginning, patrilinear time is dominant. Authority thus lies with male elders and women are relegated to the domestic arena. Oaive is a priestess but because her power is drawn from "the feminine", patrilinear ideology codes her as Other and disparages her authority. The male elders treat her with suspicion and impatience, "(fidgeting and) avoiding her eyes" (23) and beyond her village she is met with overt animosity. People readily believe that although she "might only seem a young girl (...) under it she was old and foul, with snakes for hair" (31); female magic and authority are at best humoured and at worst vilified.

Lee specifically foregrounds Oaive's alliance with the feminine through various gynocentric symbols and images. Oaive is a sea-witch/priestess which is significant because the ocean is symbolically evocative of the Cosmic Womb. As Sjoo and Mor write in The Great Cosmic Mother, a seminal work of cultural feminism: "In the beginning (...) was a very female sea. (And) in the cause of evolution, the ocean - the protective and nourishing space, the amniotic fluids, even the lunar-tidal rhythm was transferred into the individual female body" (1987:2). Because the ocean as womb is so primary a gynocentric image, Oaive is immediately Other to the patrilinear norm. Sjoo and Mor's "in the beginning" also echoes the opening lines of Genesis and counters the masculinist creation myth presented in the Bible with a "very female sea" that gives birth to life. In this context Oaive's name may take on additional significance - not only is it "a name like the sound of the sea" (8), it is pronounced "Eve" (the Celtic spelling suggests Celtic pronunciation), recalling the biblical Eve. In second-wave cultural feminism Eve was reclaimed, like other examples of the monstrous feminine, as evocative of female rebellion against patriarchal ideology. Lee's reference to Eve here is thus significant: in aligning her protagonist with both the first rebellious woman and the Great Cosmic Mother, Lee positions Oaive as an agent of subversive feminine space/time.

We also see Oaive painting spiral designs on shells, making "lucky talismans" for the villagers. Because spirals are evocative of the cyclical, the feminine and the womb, her use of them in magic again aligns her power with the Cosmic Mother. As does the fact that her weaving has magical properties, recalling the Cosmic Goddess in the forms of the Fates and Grandmother Spider, all of whom weave time (Gunn-Allen, 1986:27; Warner, 1994:14). At her loom Oaive notices two frayed threads and sees in them a "sign of severed ties, or of death itself" (25). She reads the omen, recognising that a change is coming and that she will have to weave the unravelling threads back together. Gunn-Allen tells us that as Grandmother Spider's "power to weave includes the power to unravel, so the weaver, like the moon, signifies the power of patterning and its converse, the power of disruption" (1986:27). As a weaver of feminine time Oaive's task is to reassert the full cycle of death and rebirth in order to undo the damage patrilinearity has done to her world.

As Lee weaves these symbols and symbolic activities into Oaive's everyday pattern, allying her protagonist with the Feminine, she also intimates that Oaive's lived experience of time is not governed by linearity. Oaive is sensitive to the ocean's tides, to each ebb and flow. She performs the ritual of the shrine every dusk and dawn - liminal moments belonging neither to night nor day and evocative of birth and death. As the current priestess, she also knows that even as she followed the one before her, so another will follow her - that intrinsic to the role is death and rebirth. Oaive's lived experience of time is therefore evocative of cyclical consciousness rather than patrilinear progression. To cite this article: Eileen Donaldson (2017) In Her Bones: Second Wave "Women's Time" in Tanith Lee's The Winter Players, Scrutiny2, 22:2, 112-127, DOI: 10.1080/18125441.2017.1311361 
Then a stranger steals one of the relics of the shrine: a fragment of bone. Oaive feels she must retrieve the bone at all costs and so follows him. At this point the narrative takes on the linear pattern of a quest and as linear progression orders the narrative, tension develops between what belongs to linear time and the cyclical magic that Oaive represents. This tension is succinctly reflected in Lee's characterisation of Oaive and her male antagonists. Oaive is young and passionate, her hair is a tawny red, and she calls fire from her flesh (14). She and the feminine are thus characterised as vital and living. In direct contrast Lee describes the male antagonists as colourless, desiccated and cold. The stranger is all grey - his eyes, his hair, his name - and Oaive describes him as a "winter sea" (12) because he seems frozen. The sorcerer he serves, Niwus "resembles something unfinished or bloodless" (66) and "his power (is) like the smell of winter itself" (69). Where Oaive is associated with fire, they both call up the stasis of winter. Later in the tale Grey tells Oaive that as a child he sought to prevent the death of his mentor with magic and this allowed something ancient and evil to take possession of the body - Niwus. Both male antagonists thus refuse the cycle of death and rebirth: Grey upon the death of his mentor and Niwus whose spirit has haunted the world for eons. They represent the sterility of a linear existence in which change and difference are refused.

The threat that linearity poses is hinted at in the beginning of the novel, but becomes more palpable and frightening as Oaive interacts with Grey and Niwus. Prior to Grey's arrival Oaive is worried because "the savageness of the winter grows" (22) every year and she intuits that when he steals the bone nothing stands between her village and the encroaching cold. Although she has already associated Grey with winter the link becomes clearer as she follows him to his kingdom. Here, the blight is concentrated: "it was as though a plague had passed over (the land), killing everything (and) the snow sprinkled down" (58). When Niwus and Grey refuse death they begin a temporal reaction that disrupts even the natural cycle of the seasons. The state of Grey's kingdom is a foreshadowing of what will happen to the rest of the world if Oaive cannot reinstate the balance between cyclical time and linear time, between feminine and masculine power.

There is only one thing of which Niwus is afraid: the bone Grey steals from Oaive's shrine. When he meets her he taunts her, questioning its power. He scornfully suggests that perhaps it is magical "only because generations of priestesses have venerated it and built up its power" (71), dismissing both the priestesses and the possibility that the bone is powerful in and of itself. Although Oaive knows the bone is important, she cannot answer Niwus's questions because its "explanation was lost in time" (17). But its significance is only lost to patrilinear history; Oaive will both recall and resurrect the significance of the bone when she moves into cyclical time.

When she sees the bone Oaive is taken aback at the intensity of her response - it is "like regaining her lost child, or a treasure from the sea" (71). Again, Lee grounds women's magic in gynocentric images of birth and mothering. This is why the power of the bone remains alien to Niwus. Because he senses no power in it, he hands it to Oaive. When she touches the bone, however,

She could hear instead a priestess, speaking the ritual in the shrine. It began with one voice, but shortly there were countless voices. She was hearing all the priestesses who had ever served the shrine. She was reaching back, back into the past of the shrine, back to the beginning, to the Relics themselves. (76)

The bone sweeps Oaive out of the moment in linear time and connects her to a continuum of priestesses stretching through history, drawing her into a trans-temporal, feminine space/time. Lee's continuum of priestesses is evocative of the "female continuum" motif in second wave feminist SF in which "speculative fiction's female time travellers remind women that they should look to the past and to the future - and view themselves as part of a female continuum" (Barr, 1987:46) in order to understand what female agency means and to claim it for themselves.

In this case, access to the continuum of priestesses empowers Oaive to escape Niwus: when she opens her eyes, she discovers that she has "travelled in time. And place" (80) and is back at the ocean before 
the shrine or the relics existed. Rather than being surprised she suddenly understands that she has travelled in time before, during visions. She also knows that she can now travel back and forth in time at will, that priestesses are not bound by the patrilinear. In accessing feminine space/time Oaive "(experiences), for the first time and to the full, the might of her own sorcery" (81).

In the past, she again embraces the rhythms and activities of her everyday life. When the people see her perform the ritual of the shrine on the beach and call fire from her body they adopt her, for the first time and yet once again, as their village witch. Though the relics have yet to be found, and the shrine has yet to be built, when Oaive asks about them she understands that she is initiating the belief that these objects are sacred and powerful. Everything she does here thus lays the groundwork for the magical ritual she will learn centuries from now. She feels she is "playing games with time" (85) because she is at the beginning and the end, and now the beginning again, of the sacred feminine tradition of the shrine. The repetition of Oaive's future actions in the past and her travelling from the end to the beginning creates an ouroboros-like cycle in which time becomes a generative space, full of potential futures within which nothing is settled yet.

When Oaive decides to train a few girls in the ritual of the shrine, she notices that one of them has hair that "(burns) like a dim, smoky flame" (89), like her own bronze hair. Her likeness in the girl prompts the final recognition that she herself is the first witch-priestess of the shrine and that, if this is the case, the bone after which Grey and Niwus are chasing "(is) hers. It had always been" (95). Lee writes multiple cycles into this novella, all of which consolidate the gynocentric notion of cyclical time as empowering for women. The most obvious cycle is Oaive's movement through time, which enables her to initiate the magical tradition that later empowers her. The young priestess that looks like her and the female bond of the priestesses through time also form a cycle, reinforcing the motif of the female continuum and its potential to undermine patrilinearity. And, finally, the bone that enables Oaive to access Other feminine time is her own finger-bone, suggesting that the ability to step into feminine time is natural to her: Oaive holds within herself the dynamic potential of feminine time. Having grasped this, and realising the extent of her natural power, she is now in a position to defeat the arch-patriarch, Niwus.

Grey and Niwus follow Oaive through time and arrive at the shrine. The repetition of this scene from her past and the village's future creates another temporal cycle within the text. This time, however, there are no male Elders to doubt her and when she goes to defend them the people approve of her bravery. Oaive is not afraid because she knows that if she dies, "yet still I shall live, centuries ahead of myself" (88); she draws strength from the fact that, inherent in feminine time, is this lack of finality. And it is because Oaive is no longer bound to linear time that she can defeat Niwus. He is in the process of casting a deadly spell, when she "[seems] to catch the moment like a white-cold flame between her fingers" (94). She traps him in the moment giving Grey the chance to decapitate him. In the process Grey also cuts the tip of her finger from Oaive's hand and the bone relic is created.

When all this happens as it must have happened before, Oaive is the only one who can see that history is repeating itself; she tells Grey that, "It is endless (...). We are caught on a wheel of time, turning forever" (97). Niwus has trapped all of them in a single history, repeating ad infinitum in order to ensure his own survival. In doing so he disrupts the balance between linear and cyclical time: where the beginning of each new cycle should generate new life, change, difference, Niwus has condemned time to repeat only his story - a perpetual Winter, with no hope of Spring. And it is here that Lee's narrative departs from Kristeva's second generation and moves into the scope of the third generation. In this novella Lee very plainly suggests that unmediated patrilinearity is both unnatural and problematic, not only because of its erasure of women from public time but because it refuses change and difference. She also supports the cultural feminist call to reassert the importance of feminine time for women: access to feminine time empowers Oaive to step into the fullness of her magic, something she could not do in linear time. But then Lee suggests that Niwus's pattern, always the same and always cycling is unhealthy. The plot becomes a little hazy at this point but Lee's meaning is clear: neither perpetual linearity nor perpetual cycles are helpful - both temporal modes working together are essential for living change to occur. For the generative space of feminine time to be valuable, that To cite this article: Eileen Donaldson (2017) In Her Bones: Second Wave "Women's Time" in Tanith Lee's The Winter Players, Scrutiny2, 22:2, 112-127, DOI: 10.1080/18125441.2017.1311361 
which it generates must erupt into public linear time, and for linear time to foster true progress, the linear pattern must be disturbed every so often by what cyclical time generates. To foster the becoming of her world, to free it from Niwus, Oaive must therefore use the generative potential of feminine time to shift the patrilinear pattern.

Oaive believes that the only way to disrupt the cycle is to sacrifice herself. Mircea Eliade suggests that in myth time, which is cyclical time, the act of sacrifice, "[n]ot only exactly reproduces the initial sacrifice revealed by god ab origine, at the beginning of time, it also takes place at that exact same primordial mythical moment" (Eliade, 2005:35). At the moment of her self-sacrifice Oaive thus accesses that first moment of birth contained in feminine time in order to unravel the history of the world and weave time into a new shape: she becomes the Cosmic Weaver and her sacrifice initiates the cosmogonic rebirth of her world. In practical terms she goes into the future to prevent Grey from casting the spell that allows Niwus to possess his mentor. She moves from cyclical time into linear time in order to rewrite history and sacrifices her life in the process. The novella ends here.

But in the epilogue Lee returns her readers to the fishing village of the first chapter. Temporally, we have returned to the future, and the beginning of the story but the world is different. There is no shrine, but there is a girl with flame-coloured hair and we are told, "Her name was Oaive, a name like the sound of the sea" (101). The differences between this world and Oaive's original world speak to the successful and necessary co-existence of linear and cyclical times. Previously Oaive was forced to live in isolation, rejected even by her mother because she was the priestess. In this world she is friends with two other witches her age, and "[t]hough Oaive's mother had not been a witch, they had been close. The mother was proud that her child would be a healer and a spell-maker" (101). In this world witches marry and their powers are often inherited by their daughters. Lee writes the possibility of romance for Oaive into this new ending, but because women's relationship to power is different in this time, Oaive is equal to her male partner not a witch to be despised. Witches are also called "naturals" in the epilogue, implying that women without magical powers may learn magic in a society that obviously accepts and encourages women to become learned and powerful. The Winter Players therefore finally settles into a position that reflects the approach of Kristeva's third generation: Oaive neither fights patrilinearity on its own terms, nor does she escape to a separatist women's time, instead she uses the power of feminine time to transform the patrilinear culture of her world.

Fiction such as this thus demonstrates that the perspective of Kristeva's third generation appears during the second wave. And while the strategies and approaches of the three generations are often at odds, it is important to remember that for all of them

To speak of women and time is to speak of the ultimate theft. (...) Regardless of circumstance, women are strangers in the world of male-defined time and as such are never at home there. At best, they are like guests eager to prove helpful; at worst they are refugees, living on borrowed time. (Johles-Forman, 1989:1)

Because of this, second wave feminisms agreed that the time had come to reassess and defy women's dismissal from the patrilinear agora. And second wave feminist SF had a role to play in this endeavour: authors who refused and rewove patrilinearity enabled their "female protagonists to recover, rebuild, and redefine their personal feminine archetypes of selfhood" (Barr, 1987:57). Because of this, as Marleen Barr continues, "Speculative fiction's female time travellers convey the hope that, despite the passage of hundreds of years without such feminine archetypes, real women can insist upon and achieve self-affirmation in the real world. Real women can finally make up for lost time" (1987:57).

\section{Works cited}

Baccolini, R. 2000. 'Gender and Genre in the Feminist Critical Dystopias of Katherine Burdekin, Margaret Attwood, and Octavia Butler' in Future Females, The Next Generation: New Voices and Velocities in Feminist Science Fiction (pp.13-34). Barr, M.S. (ed.) London: Rowman and Littlefield Publishers.

To cite this article: Eileen Donaldson (2017) In Her Bones: Second Wave "Women's Time" in Tanith Lee's The Winter Players, Scrutiny2, 22:2, 112-127, DOI: 10.1080/18125441.2017.1311361 
Barr, M.S. 1987. Alien to Femininity: Speculative Fiction and Feminist Theory. New York: Greenwood Press.

Beer, G. 1989. 'Representing Women: Re-presenting the Past' in The Feminist Reader: Essays in Gender and the Poetics of Literary Criticism (pp.63-80). Belsey, C. and Moore, J. (eds). London: Macmillan Education.

Braidotti, R. 1994. Nomadic Subjects: Embodiment and Sexual Difference in Contemporary Feminist Theory. New York: Columbia University Press.

Burchill, L. 2006. 'Resituating the Feminine in Contemporary French Philosophy' in Belief, Bodies and Being: Feminist Reflections on Embodiment (pp. 81-102). Orr, D., Lopez-McAlister, L., Kahl, E. and Earle, K. (eds). New York: Rowman and Littlefield Publishers.

Caputi, J. 1992. 'On Psychic Activism: Feminist Mythmaking' in The Feminist Companion to Mythology (pp. 425-440). Larrington, C. (ed.). London: Pandora Press.

Chanter, T. 2001. Time, Death and the Feminine: Levinas with Heidegger. Stanford: Stanford University Press.

Cixous, H. 1981. 'Sorties' in New French Feminism (pp90-98). Marks, E. and de Courtivron, I. (eds). Hertfordshire: The Harvester Press.

Clute, J. and Nicholls, P. 1999. The Encyclopedia of Science Fiction. Great Britain: Orbit.

Collard, A. 1988. Rape of the Wild: Man's Violence Against Animals and the Earth. London: The Women's Press.

Daly, M. 1973. Beyond God the Father: Toward a Philosophy of Women's Liberation. Boston:

Beacon Press.

Davies, K. 1990. Women, Time and the Weaving of the Strands of Everyday Life. United Kingdom:

Gower Publishing.

De Beauvoir, S. 1953. The Second Sex. London: Vintage.

Donovan, J. 2001. Feminist Theory: The Intellectual Traditions $3^{\text {rd }}$ ed. New York: Continuum.

Edinger, E.R. 1968. 'An Outline of Analytical Psychology'. www.israjung.co.il/edinger.htm.

Accessed 20 January 2011.

Eliade, M. 2005. (translated by Trask, W.). Myth of the Eternal Return: Cosmos and History. New Jersey: Princeton University Press.

Evans, J. 1995. Feminist Theory Today: An Introduction to Second Wave Feminism. London: SAGE Publications.

Gottner-Abendroth, H. 1984. 'Urania - the Time and Space of the Stars: The Matriarchal Cosmos through the Lens of Modern Physics' in Taking Our Time: Feminist Perspectives on Temporality (pp. 108-119). Johles-Forman, F. and Sowton, C. (eds). Oxford: Pergamon Press.

Gunn-Allen, P. 1986. The Sacred Hoop: Recovering the Feminine in American Indian Tradition. Boston: Beacon Press.

Haraway, D. 1991. 'A Cyborg Manifesto: Science, Technology, and Socialist Feminism in the Late Twentieth Century' in Symians, Cyborgs and Women: The Reinvention of Nature. New York:

Routledge.

Higgins, D.M. 2009. 'Science Fiction, 1960-2005: Novels and short fiction' in Women in Science Fiction and Fantasy (pp. 73-83). Reid, R.A. (ed.) Connecticut: Greenwood Press.

Jardine, A. 1985. Gynesis: Configurations of Women and Modernity. London/Ithaca: Cornell University Press.

Johles-Forman, F. and Sowton, C. (eds). 1989. Taking Our Time: Feminist Perspective on Temporality. Oxford: Pergamon Press.

King, K. 1994. Theory in its Feminist Travels: Conversations in US Movements. Bloomington: Indiana University Press.

Kristeva, J. 1986. 'Women's Time' in The Kristeva Reader (pp. 187-213). Moi, T. (ed.). London: Basil Blackwell.

Larrington, C. (ed.). 1992. The Feminist Companion to Mythology. London: Pandora Press.

Lee, T. 1988. The Winter Players. London: Beaver Books.

Leif-Davin, D. 2009. 'Science Fiction, 1900-1959, Novels and short fiction' in Women in Science Fiction and Fantasy (pp. 44-55). Reid, R.A. (ed.) Connecticut: Greenwood Press.

Mains, C. 2009. 'Fantasy, 1900-1959: Novels and short fiction' in Women in Science Fiction and Fantasy (pp. 34-44). Reid, R.A. (ed.) Connecticut: Greenwood Press.

To cite this article: Eileen Donaldson (2017) In Her Bones: Second Wave "Women's Time" in Tanith Lee's The Winter Players, Scrutiny2, 22:2, 112-127, DOI: 10.1080/18125441.2017.1311361 
Mitchell, J. 1984. Woman, the Longest Revolution: Essays in Feminism, Literature and Psychology. London: Virago.

Murphy, P. 2001. Time is of the Essence: Temporality, Gender and the New Woman. Albany: State of New York University Press.

Orr, D. 2006. 'Thinking Through the Body: An Introduction to Beliefs, Bodies and Beings' in Belief, Bodies and Being: Feminist Reflections on Embodiment (pp. 1-10). Orr, D., Lopez-McAllister, L., Kahl, E., and Earle, K. (eds). New York: Rowman and Littlefield Publishers.

Pearson, C. 'Coming Home: Four feminist utopias and Patriarchal experience' in Future Females: A Critical Anthology (pp. 63-70). Barr, M.S. (ed.). Ohio: Bowling Green State University Popular Press. Pfeuffer-Kahn, R. 1989. 'Women and Time in Childbirth and During Lactation' in Johles-Forman, F. and Sowton, C. (eds). Taking Our Time: Feminist Perspective on Temporality. Oxford: Pergamon Press.

Pratt, A., White, B., Loewenstein, A. and Wyer, M. 1981. Archetypal Patterns in Women's Fiction. Bloomington: Indiana University Press.

Stansell, C. 2010. The Feminist Promise: 1792 to the Present. New York: Modern Library.

Sjoo, M. and Mor, B. 1987. The Great Cosmic Mother: Rediscovering the Religion of the Earth. New York: Harper Collins.

Tong, R. 1989. Feminist Thought: A Comprehensive Introduction. London: Routledge.

Ulanov, A. 1971. The Feminine in Jungian Psychology and in Christian Theology. Evanston:

Northwestern University Press.

Warner, M. 1994. From the Beast to the Blonde: on Fairytales and their Tellers. London: Vintage. Whelehan, I. 1995. Modern Feminist Thought: From the Second Wave to 'Post-Feminism'. New York: New York University Press. 